\title{
ANALISIS KEMAMPUAN PENALARAN MATEMATIS SISWA MTS DI KABUPATEN CIANJUR PADA MATERI TEOREMA PYTHAGORAS
}

\author{
Tsiyaab Sundus Nurkhaeriyyah $^{1}$, Euis Eti Rohaeti ${ }^{2}$, Anik Yuliani ${ }^{3}$ \\ 1,2,3 IKIP Siliwangi, Jln Terusan Jendral Sudirman Cimahi, Jawa Barat, Indonesia \\ ${ }^{1}$ sunsunsundus18@gmail.com, ${ }^{2}$ e2rt@ikipsiliwangi.ac.id, ${ }^{3}$ anik_yuliani070886@yahoo.com
}

\begin{abstract}
This article is an analysis of the results of the test mathematical reasoning of grade IX students of Junior High School. The analysis focused to identify and recognize the qualities of difficulties experienced by students and to autheticate the mathematical reasoning level at the nineth grade students of junior high school in Kabupaten Cianjur. Qualitative descriptive is used as the research method. The samples brought for this research are 19 students of class IX in one of junior high school in Kabupaten Cianjur. Instrument test of reasoning ability of mathematic given as many as 6 items. The output of the analysis obtained based on written tests conducted is the degree of ability mathematical reasoning at students of junior high school in Kabupaten Cianjur is still classified low.
\end{abstract}

Keywords: Mathematical Reasoning

\begin{abstract}
Abstrak
Artikel ini merupakan analisis terhadap hasil test soal kemampuan penalaran matematis siswa kelas IX Madrasah Tsanawiyyah. Analisis ini dilakukan bertujuan untuk mengetahui serta mengenali jenis-jenis kesulitan yang dialami oleh siswa dan untuk mengetahui tingkat penalaran matematis siswa MTs di Kabupaten Cianjur. Penelitian ini menggunakan metode kualitatif deskriptif. Sejumlah 19 orang siswa MTS kelas IX di Kabupaten Cianjur digunakan sebagai sampelnya. Instrumen tes kemampuan penalaran matematis yang diberikan sebanyak 6 butir soal. Hasil analisis yang diperoleh berdasarkan tes tertulis yang dilakukan adalah bahwa kemampuan penalaran matematis murid MTs di Kabupaten Cianjur masih tergolong rendah.
\end{abstract}

Kata Kunci: Penalaran Matematis, Teorema Phytagoras

How to cite: Nurkhaeriyyah, T. S., Rohaeti, E.E.(2018). Analisis Kemampuan Penalaran Matematis Siswa MTs Di Kabupaten Cianjur pada Materi Teorema Pythagoras. JPMI Jurnal Pembelajaran Matematika Inovatif, 1 (5), 827-836.

\section{PENDAHULUAN}

Posisi pendidikan yang strategis dalam pembangunan bangsa saat ini dan ke-depan, menjadikan pencapaian tujuan pendidikan nasional teramat penting. Pemahaman akan hal ini telah nampak dalam berbagai upaya pemerintah bersama masyarakat, sehingga anggaran pendidikan melonjak naik dalam APBN dan APBD diseluruh daerah. Ragam upaya dari sudut yang lain juga telah dilakukan. Setelah kurikulum yang tak henti untuk dikaji ulang, pengembangan pembelajaran pun menjadi hal yang sangat penting (Yuliani, 2013).

Matematika merupakan salah satu bidang studi yang menjadi perhatian utama, dan dalam kenyataannya pun masih dianggap pelajaran yang rumit untuk dimengerti dan dipahami oleh peseta didik bahkan ditakuti oleh mayoritas siswa. Ruseffendi mengemukakan bahwa pada umumnya anak-anak tidak 
begitu menyukai pelajaran matematika kalau bukan sebagai sesuatu yang dibenci oleh mereka. Karenanya, semenjak awal guru matematika khususnya harus dapat meyakinkan murid-muridnya bahwa yang diajarkan kepada mereka itu tidaklah sulit namun dapat menjadi mudah dan menyenangkan serta menjadi kebutuhan hidup, mesti dipergunakan sedemikian rupa supaya bisa benar-benar memberikan manfaat untuk kehidupan (Sugianto, Armanto, \& Harahap, 2004).

Tujuan pembelajaran matematika yakni: (1) melatih bagaimana memahami sesuatu melalui berpikir dan bernalar untuk menarik suatu kesimpulan, (2) mengembangkan kreativitas peserta didik dengan melibatkan insting, fantasi, dan suatu penciptaan yang dikembangkan dari pemikiran kuriositas, divergen, otentik, sehingga dapat membuat perkiraan untuk mengatasi persoalan yang dihadapi, (3) mengelaborasi kemampuan memecahkan masalah, dan (4) menyerkah kemampuan menyampaikan informasi dan mengkomunikasikan gagasan (Annisa, Sholihat, Hidayat, \& Rohaeti, 2018).

Tujuan pembelajaran matematika lain yang tertuang dalam NCTM yang menetapkan bahwa kemampuan pemecahan masalah, penalaran dan validasi, komunikasi, koneksi, dan representasi merupakan kemampuan yang semestinya dimiliki oleh peserta didik (Yuliani, 2015).

Menurut NCTM pula kemampuan ini adalah kunci dari materi matematika, sehingga menjadi 'principal part' atau bagian utama dalam pembelajarannya. Bernalar matematik merupakan suatu kebiasaan, layaknya kebiasaan lain, maka perlu dikembangkan melalui penggunaan secara konsekwen serta kontinu dalam berbagai konteks. Orang yang berpikir dan bernalar secara analitik akan condong lebih mengetahui corak, susunan, atau keteraturan pada simbol-simbol maupun di kehidupan sehari-hari (Nurhayati \& Subekti, 2017).

Subagyo (2007) mengatakan bahwa agar kemampuan-kemampuan matematis dapat berkembang secara maksimal, siswa semestinya mempunyai kesempatan yang terbuka untuk berpikir dan berkreatifitas dalam memecahkan berbagai permasalahan yang dihadapi.

Melalui pembelajaran matematika diharapkan cara berpikir siswa dapat bertumbuh dengan optimal karena matematika mempunyai susunan dan sangkutan yang erat dan jelas antara konsep-konsep. Demikian maka matematikan sangat memungkinkan untuk dapat manaikkan penalaran yang dimaksud. NCTM menyatakan bahwa, reasoning is an integral portion of carry out mathematics. Students have to join the middle grades with the opinion that mathematics invcriminates examining patterns and noting regularities, creating conjectures about opening lavelings, and apreciating the conjectures. Pernyataan tersebut bermakna bahwa penalaran merupakan potongan yang tidak terpisahkan dari matematika. Pada tingkat sekolah menengah, siswa harus memiliki pandangan serta pengetahuan bahwa dalam matematika melibatkan kegiatan memeriksa pola dan mencatat keteraturan, membuat dugaan tentang memungkinkan adanya generalisasi, dan mengevaluasi dugaan (Wibowo, 2017). Oleh karena itu menurut Hidayat, Herdiman, Aripin, Yuliani \& Maya (2018) mengatkan bahwa kemampuan penalaran harus di kembangkan oleh peserta didik agar mampu menyelesaikan masalah, menilai secara kritis dan mengungkapkan ide secara logis.

Kilpatrick, Swafford \& Findell menyatakan bahwa penalaran merujuk pada kemampuan memformulasikan dan menggambarkan masalah matematika serta menjelaskan dan menjustifikasi solusi atau argumen (Ulya, Yuwono, \& Qohar, 2017). Kemudian akan ditarik kesimpulan bahwa penalaran matematis adalah suaatu proses menarik kesimpulan logis dari fakta matematis yang diketahui atau diasumsikan.

Satu dari sekian banyaknya konsep yang diajarkan di sekolah pada bidang studi matematika ini adalah geometri. Geometri dipelajari di seluruh tingkat pendidikan, dimulai dari SD, SMP, dan SMA, bahkan hingga ke Perguruan Tinggi sekalipun. Dalam pembelajarannya, geometri meliputi bangun-bangun geometri (bidang datar dan bangun ruang), garis dan sudut, kesebangunan, kekongruenan, transformasi, dan geometri analitis (Guntoro, Ratu, \& Yunianta, 2016). Sayangnya, konsep dari geometri yang dipelajari sejak SD terbilang masih belum dikuasai oleh mayoritas siswa. Salah satu diantaranya itu 
yakni teorema Pythagoras. Teorema Pythagoras ini atau dikenal juga sebagai dalil pythagoras merupakan suatu teorema yang meunjukkan hubungan sisi-sisi pada segitiga siku-siku.

Menyikapi hal demikian maka peneliti merasa perlu melakukan penelitian untuk menyelidiki sejauh mana kemampuan tersebut pada siswa MTs di Cianjur atas materi ini. Dengan rumusan masalahnya adalah materi teorema Pythagoras dengan kemampuan penalaran matematis siswa MTs di Kabupaten Cianjur.

\section{METODE}

Penelitian ini merupakan penelitian kualitatif deskriptif, yang memiliki tujuan untuk memaparkan dan menjelaskan cara siswa dalam memecahkan soal teorema pythagoras dilihat dari kualitas kemampuan penalaran matematis siswa. Data penelitian ini berupa jawaban tertulis yang diperoleh dari tes tertulis yang dilakukan. Sampel pada penelitian ini adalah 19 orang siswa kelas IX di salah satu MTs di Kabupaten Cianjur. Adapun soal yang diberikan yaitu 6 butir pertanyaan kemampuan Penalaran matematis dengan materi teorema pythagoras dalam bentuk uraian.

\section{HASIL DAN PEMBAHASAN}

\section{Hasil}

Tabel 1. Rincian Hasil Analisis Uji Coba Tes Kemampuan Penalaran Matematis dari Materi Teorema Pythagoras

\begin{tabular}{|c|c|c|c|c|c|c|c|c|c|}
\hline \multirow[t]{2}{*}{$\begin{array}{l}\text { NO } \\
\text { SOAL }\end{array}$} & \multicolumn{2}{|c|}{ VALIDITAS } & \multicolumn{2}{|c|}{ RELIABILITAS } & \multicolumn{2}{|c|}{$\begin{array}{c}\text { Daya } \\
\text { Pembeda }\end{array}$} & \multicolumn{2}{|c|}{$\begin{array}{c}\text { Indeks } \\
\text { Kesukaran }\end{array}$} & \multirow[t]{2}{*}{ INTERPRETASI } \\
\hline & $r_{x y}$ & Makna & $r_{11}$ & Makna & DP & Makna & IK & Makna & \\
\hline 1 & 0,5678 & Sedang & & & 0,313 & Cukup & 0,344 & Sedang & DIPAKAI \\
\hline 2 & 0,7146 & Tinggi & & & 0,938 & $\begin{array}{c}\text { Sangat } \\
\text { Baik }\end{array}$ & 0,844 & Mudah & DIPAKAI \\
\hline 3 & 0,8354 & Tinggi & 0,832 & Tinggi & 0,563 & $\begin{array}{c}\text { Sangat } \\
\text { Baik }\end{array}$ & 0,719 & Mudah & DIPAKAI \\
\hline 4 & 0,8753 & Tinggi & & & 0,563 & Baik & 0,406 & Sedang & DIPAKAI \\
\hline 5 & 0,8117 & Tinggi & & & 0,438 & Baik & 0,281 & Sukar & DIPAKAI \\
\hline 6 & 0,6748 & Sedang & & & 0,500 & Baik & 0,500 & Sedang & DIPAKAI \\
\hline
\end{tabular}

Penelitian ini dilakukan pada sembilan belas (19) orang siswa dikelas IX. Berikut ini disajikan tabel persentase jawaban siswa tiap butir soal.

Tabel 2. Persentase Jawaban Siswa Tiap Butir Soal

\begin{tabular}{cccccccc}
\hline \multirow{2}{*}{$\mathrm{x}$} & \multicolumn{7}{c}{ Indikator / Soal } \\
\cline { 2 - 6 } & 1 & 2 & 3 & 4 & 5 & 6 & Skor \\
\hline$\%$ & $9,21 \%$ & $30,26 \%$ & $11,84 \%$ & $15,79 \%$ & $9,21 \%$ & $42,10 \%$ & $19,74 \%$ \\
\hline SD & 0,96 & 1,06 & 1,17 & 0,92 & 0,95 & 1,79 & 5,49 \\
\hline
\end{tabular}

\section{Pembahasan}

a. Analisis soal no 1

Butir soal pertama dengan indikator memberikan penjelasan dengan model, fakta, sifat-sifat, dan hubungan adalah sebagai berikut: 
Perhatikan denah lokasi berikut!

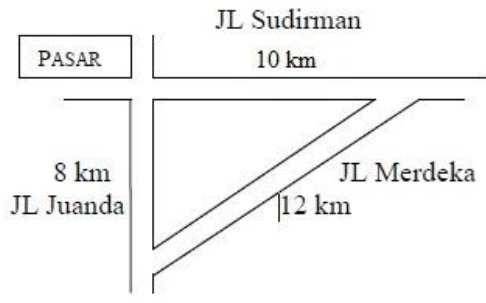

Terdapat sebuah pasar terletak pada pertemuan dua jalan, yaitu Jl. Juanda dan Jl. Sudirman. Keduanya dihubungkan oleh satu jalan yang lain, yaitu Jl. Merdeka. Jika pemerintah kota ingin menghubungkan Jl. Merdeka ke pertemuan J1. Juanda dan Jl. Sudirman, sehingga jaraknya terpendek.

A. Gambarlah lokasi pada Jl. Merdeka yang menghubungkan jalan tersebut ke pertemuan Jl. Juanda dan Jl. Sudirman, sehingga jaraknya terpendek!

B. Bagaimana posisi jarak terpendek tehadap jalan merdeka?

Jawaban siswa 1:

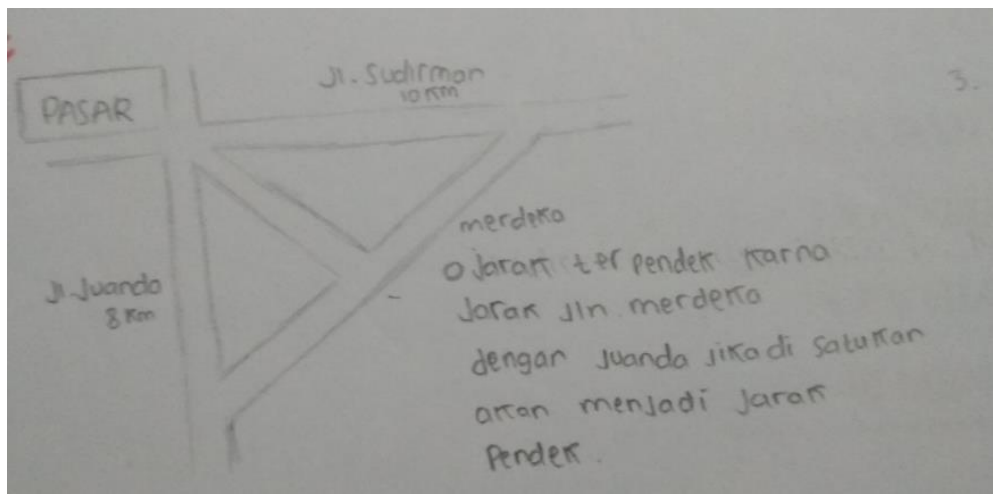

Gambar 1. Kesalahan Jawaban Siswa Soal Ke-1

Jawaban siswa 2:

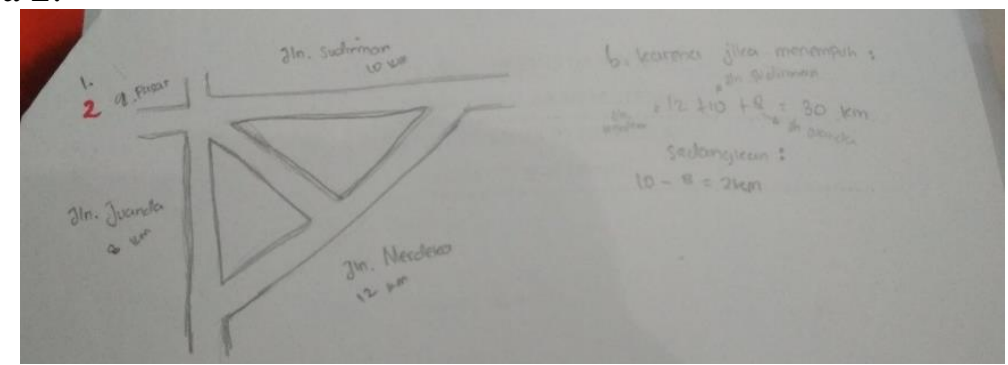

Gambar 2. Kesalahan Penyelesaian Siswa Soal pertama

Kemungkinan kesulitan yang terjadi ketika menjawab permasalahan diatas adalah siswa belum menguasai betul konsep atau prasyarat mengenai teorema Pythagoras. Jawaban yang diminta mengenai posisi terpendek itu adalah terbentuknya sudut $90^{\circ}$ dengan posisi yang silih tegak lurus Namun, siswa belum bisa menjelaskan secara jelas mengenai posisi jalan yang baru terhadap jalan mereka yang dimaksud dan malah memberikan penyataan yang lain.

b. Analisis soal no 2

Butir soal nomor 2 dengan indikator menyusun argumen yang valid; mengikuti aturan inferensi dan memeriksa validitas adalah sebagai berikut:

Temukan gambar yang manakah yang bisa digunakan dalam Pythagoras ! sertakan alasanmu !

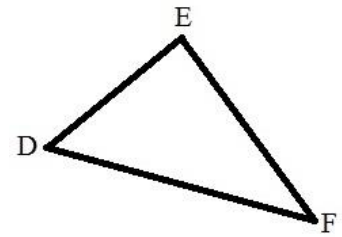


a.

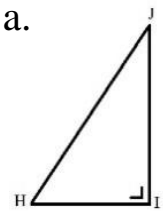

b.

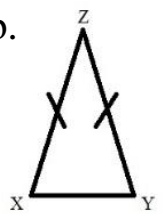

c.

d.

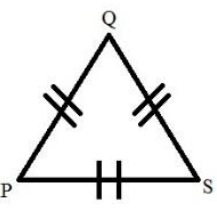

e

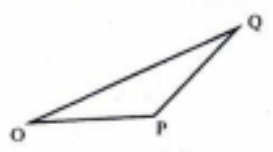

f.

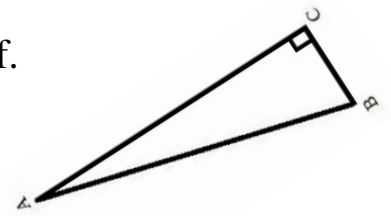

Jawaban siswa 1:

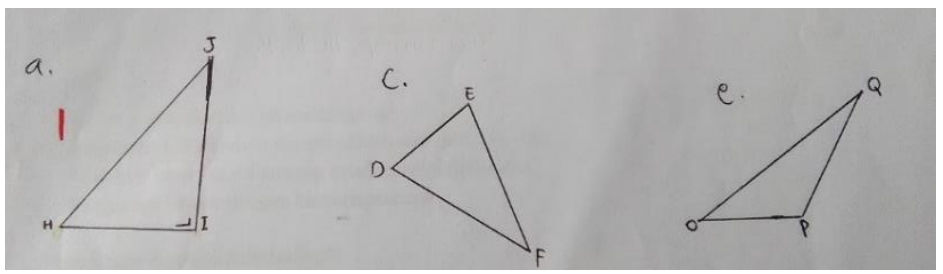

Gambar 3. Kesalahan Pengerjaan Soal Nomor 2

Jawaban siswa 2:

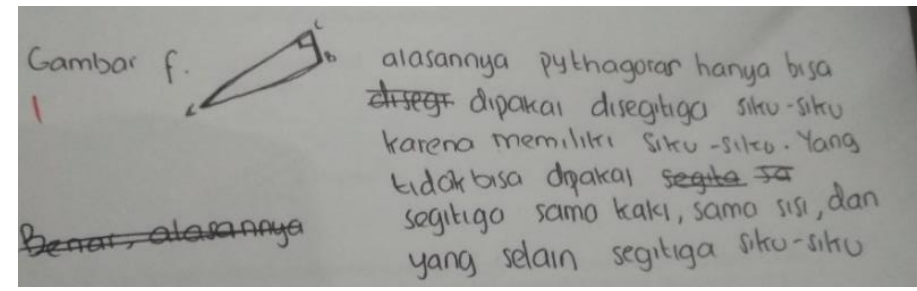

Gambar 4. Jawaban Siswa terhadap Soal Kedua

Kendala yang mungkin dirasakan oleh siswa dalam pengerjaan soal tersebut adalah mereka masih kebimbangan untuk menetapkan gambar mana yang tepat dan kesulitan menuliskan alasan mengapa ia memilih gambar-gambar tersebut, tampaknya hal ini terjadi jika siswa belum menguasi konsep atau prasyarat mengenai teorema pythagoras. Walau demikian gambar yang dipilihnya sudah tepat meskipun masih ditemukan kelalaian dalam pemilihannya karena tidak yakin dengan posisi gambar yang tidak sepeti biasanya.

c. Analisis soal no 3

Butir soal ke-3 dengan indikator menyusun pembuktian langsung, tak langsung, dan menggunakan induksi matematis; merumuskan lawan contoh adalah sebagai berikut: Perhatikan ilustrasi dibawah ini !

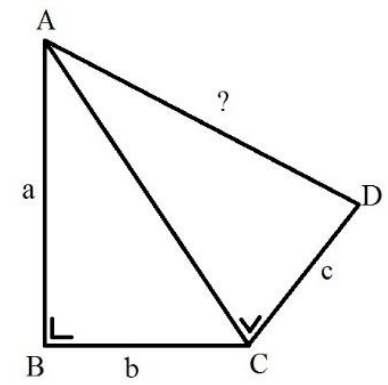


Tentukan panjang AD dan nyatakan dalam bentuk a,b,c, jika panjang $\mathrm{AB}$ adalah $12 \mathrm{~cm}$, $\mathrm{BC}$ adalah $9 \mathrm{~cm}$, dan $\mathrm{CD}$ adalah $8 \mathrm{~cm}$. Kemudian carilah bilangan lain untuk memenuhi nilai a,b,c !

Jawaban siswa 1:

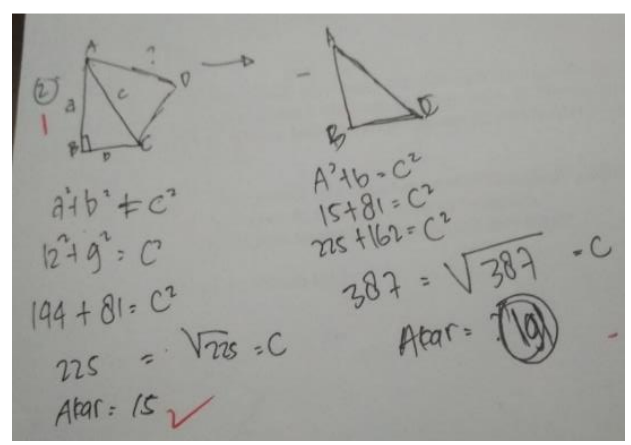

Gambar 5. Kesalahan Siswa Menjawab Soal Ketiga

Jawaban siswa 2:

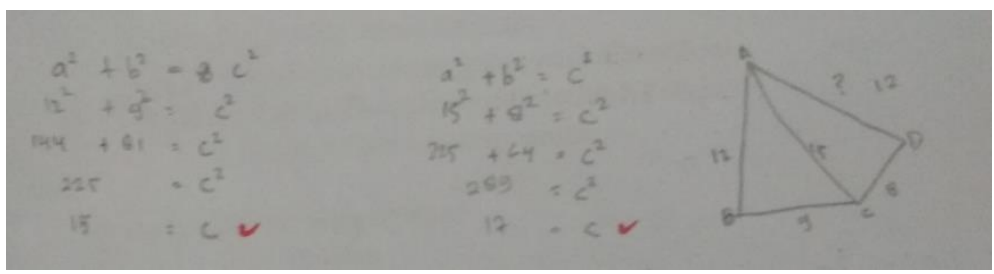

Gambar 6. Jawaban Siswa pada Soal Nomor 3

Dalam pengerjaan soal ini, kesulitan yang banyak dihadapi oleh siswa yaitu keliru pemahaman terhadap konsep perhitungan bilangan yang terdapat pada tanda akar, sehingga kurang teliti ketika melakukan perhitungannya. Juga siswa kurang seksama dalam memahami soal yang mengakibatkan mereka tidak dapat menginterpretasikan soal dengan baik sehingga tidak mengetahui penyelesaian dari soal yang diberikan.

d. Analisis soal no 4

Butir soal keempat memiliki indikator menyusun dan menguji konjektur; Memperkirakan jawaban dan proses solusi adalah sebagai berikut:

Perhatikan gambar berikut!

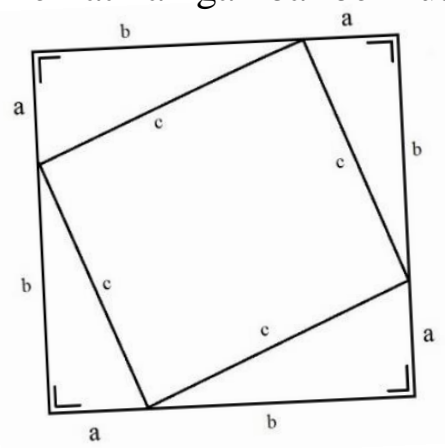

Berdasarkan gambar tersebut benarkah bahwa $\mathrm{a}^{2}+\mathrm{b}^{2}=\mathrm{c}^{2}$ ?

Sertakan alasanmu!

Jawaban siswa 1: 


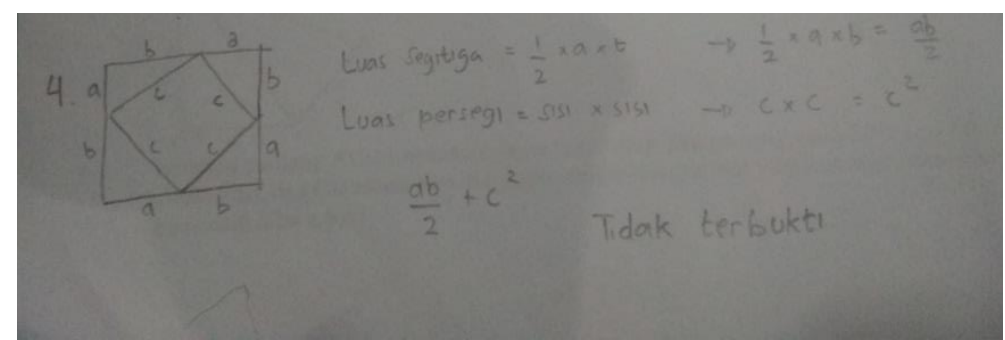

Gambar 7. Kesalahan Jawaban Siswa Soal Ke-4

Kelemahan ketika mengerjakan soal ini adalah konsep prasyarat yang dipahami oleh siswa masih termuat kekeliruan sehingga dalam pengerjaan sekaligus perhitungan siswa belum mampu menyelesaikan soal dengan baik.

e. Analisis soal no 5

Butir soal kelima dengan indikator menarik kesimpulan logis adalah sebagai berikut: Diketahui segitiga $\mathrm{ABC}$ dengan $\mathrm{AB}=12 \mathrm{~cm}, \mathrm{BC}=10$, dan $\mathrm{AC}=8 \mathrm{~cm}$. Tentukan panjang garis berat jika ditarik dari masing-masing titik $\mathrm{A}, \mathrm{B}$, dan $\mathrm{C}$ !

Jawaban siswa 1:

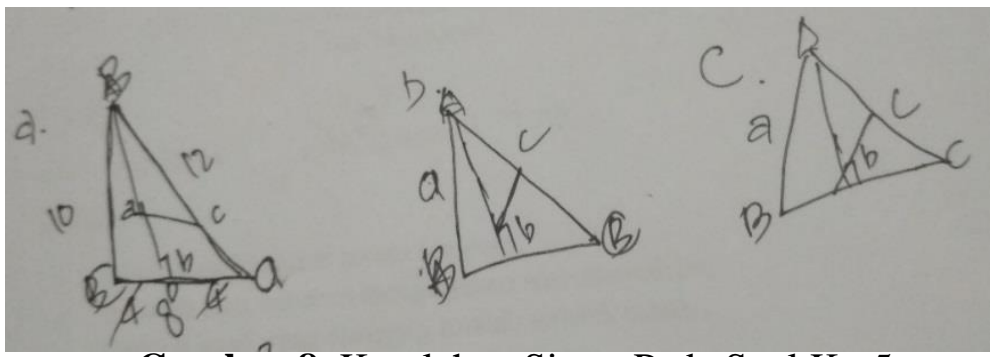

Gambar 8. Kesalahan Siswa Pada Soal Ke-5

Jawaban siswa 2:

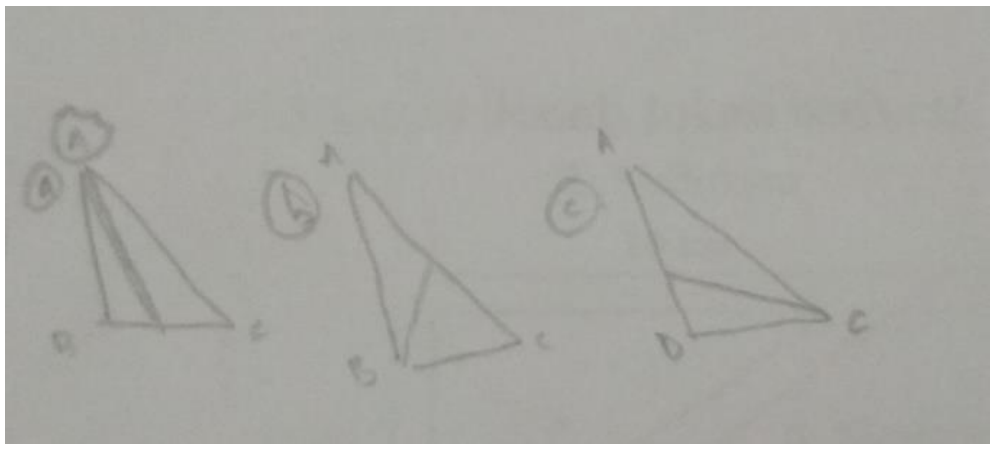

Gambar 9. Jawaban Siswa Soal Nomor 5

Jawaban siswa 3:

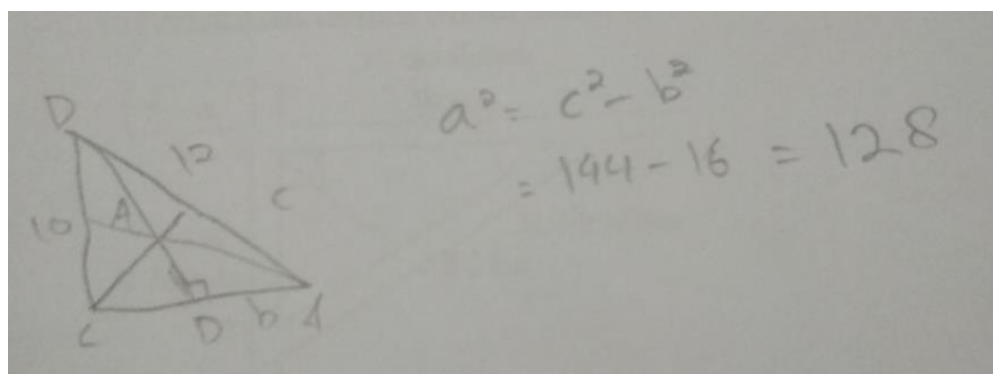

Gambar 10. Jawaban Siswa Soal Nomor 5

Konsep prasyarat mengenai materi yang dimiliki oleh murid dalam mengerjakan permasalahan ini masih terbilang keliru, yang menyebabkan penginterpretasian 
terhadapnya juga kemudian menjadikannya sulit dalam penyelesaian soal yang diberikan meskipun definsi dari pertanyaan yang dimaksudkan telah diketahui olehnya. Kesulitan lain yang ditemukan adalah mereka kesulitan memahami tujuan dari soal tersebut karena tidak paham dengan apa yang diminta dari pertanyaan yang dimaksud.

f. Analisis soal no 6

Butir soal keenam dengan indikator menggunakan pola dan kaitan untuk menganalisis situasi, atau membuat analogi dan generalisasi adalah sebagai berikut:

Perhatikan gambar dibawah ini !

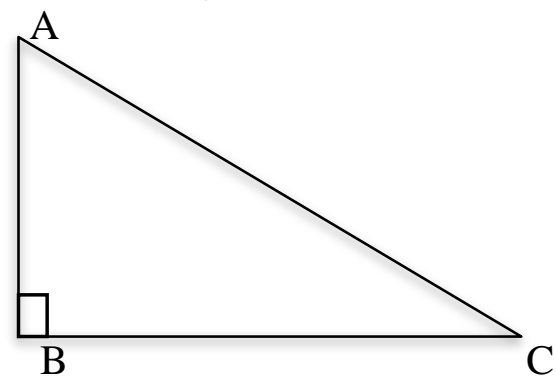

Jika panjang $\mathrm{AC}$ adalah $12 \sqrt{3}$ dan besar sudut $\mathrm{C}$ adalah $30^{\circ}$, tentukan panjang $\mathrm{AB}$ dan $\mathrm{BC}$ !

Jawaban siswa :

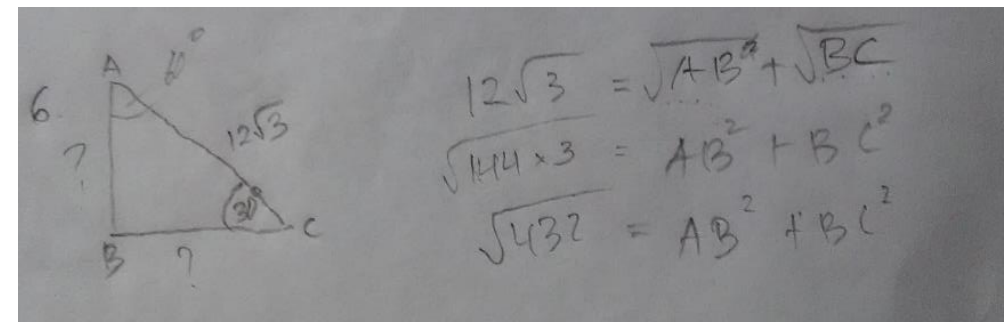

Gambar 11. Kesalahan Jawaban Siswa Soal Ke-6

Ketika mengerjakan soal dengan indikator ini kesalahan yang ditemukan adalah kurang cermatnya siswa saat mengartikan soal kemudian tidak dapat menginterpretasikan masalah dengan baik sehingga tidak mengetahui penyelesaian dari permasalahan yang diberikan.

\section{SIMPULAN}

Berdasarkan pada hasil dan pembahasan, yang dapat disimpulkan dari beberapa kesalahan siswa ketika menjawab soal penalaran matematis.

a. Kurangnya penguasaan konsep atau materi prasyarat mengenai teorema pythagoras,

b. Dalam merencanakan penyelesaian atau memberikan solusi masih kurang tepat, dikarenakan tidak mengerti maksud dari persoalan yang diberikan,

c. Terdapat kesalahan menginterpretasikan soal sehingga tidak dapat menyelesaikan pesoalan dengan tepat.

d. Ketika melakukan perhitungan, siswa kurang teliti dalam melakukan proses yang mereka digunakan untuk menyelesaikan persoalan masih kurang tepat, yang merupakan produk dari kurangnya kemampuan memahami masalah, dan merencanakan atau mengemukakan solusi yang akan digunakan. 
Dengan demikian, merujuk pada hasil analisis dari sampel siswa kelas IX di salah satu MTs di Kabupaten Cianjur, menunjukan bahwa tingkat kemampuan penalaran matematis siswa masih terbilang dibawah rata-rata.

\section{UCAPAN TERIMA KASIH}

Saya ucapkan terimakasih kepada semua pihak, baik yang terkait dan terlibat baik secara langsung maupun tidak dalam penyusunan dan penulisan jurnal ini. Termasuk didalamnya pimpinan IKIP Siliwangi, dosen pembimbing, dan pihak-pihak yang tidak dapat disebutkan satu per-satu.

\section{DAFTAR PUSTAKA}

Annisa, N., Sholihat, N., Hidayat, W., \& Rohaeti, E. E. (2018). Penghargaan Diri dan Penalaran Matemais Siwa MTs. Jurnal Pembelajaran Matematika Inovatif, 1(3), 299-304.

Guntoro, S. A., Ratu, N., \& Yunianta, T. N. H. (2016). Konsepsi Siswa tentang Teorema Pythagoras Kelas VIII SMP Negeri 10 Salatiga, F-LIB-081.

Hidayat, W., Herdiman, I., Aripin, U., Yuliani, A., \& Maya, R. (2018). Adversity Quotient (AQ) dan Penalaran Kreatif Matematis Mahasiswa Calon Guru. Jurnal Elemen, 4(2), 230-242.

Nurhayati, E., \& Subekti, F. E. (2017). Deskripsi Kemampuan Penalaran Matematis Siswa Ditinjau dari Gaya Belajar dan Gender. Alphamath, 3(1).

Subagyo, A. (2007). Studi Kelayakan Teori dan Aplikasi. Jakarta: PT Elex Media Komputindo.

Ulya, I., Yuwono, I., \& Qohar, A. (2017). Pengembangan Perangkat Pembelajaran Bercirikan Penemuan Terbimbing untuk Meningkatkan Kemampuan Penalaran Matematis Siswa pada Materi Barisan Aritmetika dan Geometri Kelas X. Jurnal Kajian Pembelajaran Matematika, 1(1).

Wibowo, A. (2017). Pengaruh Pendekatan Pembelajaran Matematika Realistik dan Saintifik terhadap Prestasi Belajar, Kemampuan Penalaran Matematis dan Minat Belajar. Jurnal Riset Pendidikan Matematika, 1(4), 1-10.

Yuliani, A. (2013). Evaluasi terhadap Bahan Ajar Matematika Berbasis PMRI di Bandung Raya. Aksioma, 4(2).

Yuliani, A. (2015). Meningkatkan Kemampuan Komunikasi Matematik pada Mahasiswa Melalui Pendekatan Contextual Teaching and Learning (CTL). Jurnal Infinity, 4(1), 1-9. 
